\title{
Media accounts of school performance: Reinforcing dominant practices of accountability
}

\section{Aspa Baroutsis}

The University of Queensland, School of Education, Brisbane, Australia a.baroutsis@uq.edu.au

\begin{abstract}
Media reportage often act as interpretations of accountability policies thereby making the news media a part of the policy enactment process. Within such a process, their role is that of policy reinforcement rather than policy construction or contestation. This paper draws on the experiences of school leaders in regional Queensland, Australia, and their perceptions of the media frames that are used to report on accountability using school performance. The notion of accountability is theorised in terms of media understandings of 'holding power to account', and forms the theoretical framework for this study. The methodological considerations both contextualise aspects of the schools involved in the study, and outline how 'framing theory' was used to analyse the data. The paper draws on a number of participant experiences and newspaper accounts of schools to identify the frames that are used by the press when reporting on school performance. Three frames referring to school performance are discussed in this paper: those that rank performance such as league tables; frames that decontextualise performance isolating it from school circumstances and levels of funding; and frames that residualise government schools.
\end{abstract}

Keywords: accountability, performativity, newspaper representation of schools, NAPLAN, school performance

\section{Acknowledgements}

This work was supported by the Australian Research Council (ARC) under Grant LP100200841. I would like to acknowledge the generous feedback on earlier drafts of this paper provided by Bob Lingard.

\section{Introduction}

Newspapers provide public accounts of the practices in schools, as well as the actions of their students and teachers. While there is enormous potential for newspapers to provide affirmative 
narratives of the good work undertaken in schools, it is often the negative, critical, oppressive, and reductionist discourses that are circulated in the press (Baroutsis, 2014). These discourses include perceptions of schools in crisis (Cohen, 2010; Hattam, Prosser, \& Brady, 2009; Snyder, 2008; Stack, 2006; Thomas, 2006), where schools are 'named, shamed, and blamed' in the media (Elstad, 2009), in particular through the use of measurement data that 'compares and ranks' schools in terms of student results on high-stakes testing regimes (Mockler, 2013; Stack, 2006; Warmington \& Murphy, 2004). Schools are the subject of ‘backlash politics’ (Gutiérrez, Asato, Santos, \& Gotanda, 2002) in the media where they are categorised and often marginalised for their performance on standardised tests. These public accounts of schools portray public education systems, globally, as being damaged and in a state of crisis (Berliner \& Biddle, 1995).

Such media accounts of schools validate distrust of educators. Public suspicion of school accountability practices and distrust of educators have contributed towards the rise of a global education reform movement (GERM) that focuses on 'stronger' accountability measures in education systems (Sahlberg, 2011). While contentious, this global reform agenda, framed around the political economic ideology of neoliberalism, supports the perception that greater topdown accountability, more competition between schools, and more test-based accountability will generate better school performance and measurement data and that can be utilised to improve student learning outcomes (Sahlberg, 2010). While neoliberal accountability asserts test-based accountability will improve both school and student performance, the evidence suggests that this simply encourages 'performativity’ (Ball, 2003; Connell, 2013; Lingard, 2010, 2011).

Ball (2003) defines performativity as ‘a technology, a culture and a mode of regulation that employs judgements, comparisons and displays as means of incentive, control, attrition and change - based on rewards and sanctions (both material and symbolic)' (p. 216). Thus, test- 
accountability agendas encourage performativity, perhaps as an unintended consequence, where schooling becomes focused on simply maximising performance data and improving test scores. In so doing, this situation neglects the broader goals of schooling such as the Australian goals of developing young people who are 'successful learners, confident and creative individuals, and active and informed citizens' (DEEWR, 2008, p. 8).

The increased emphasis on accountability in school systems and communities has led to an enhanced focus on policy technologies, such as performativity. Performativity has also been expressed as a technology of governance (Nóvoa \& Yariv-Mashal, 2003), that creates junctures for the increased regulation and control of teachers and schools, whereby 'measures of productivity or output, or displays of “quality”' can be determined (Ball, 2003, p. 216). These measures are then presumed to function as a 'production of proof' of a perceived quality (Lyotard, 1984, p. 46). Such neoliberal practices produce an obsession with 'measurements and comparisons' (Lipman, 2009, p. 68); where teachers and schools are increasingly 'policed' and subjected to greater scrutiny as a result of accountability practices and policies (Apple, 2006, p. 42).

The media are key actors in accountability policy enactment. Braun, Maguire, and Ball (2010) suggest that policies are not simply implemented, but 'enacted' as they are 'interpreted and "translated" by diverse policy actors' (p. 549). This paper argues that media reportage acts as interpretations of accountability policies, demonstrating that the media are part of the enactment process. However, their role is that of policy reinforcement rather than policy construction or indeed contestation of policy. The paper investigates the experiences of school leaders in regional Queensland, Australia, and their perceptions of the media frames that are used to report on school performance: in particular, media practices associated with the reportage of National 
Assessment Program - Literacy and Numeracy (NAPLAN) ${ }^{1}$ results and the production of league tables from these data, which act as practices of accountability that emphasise performativity. The paper theorises the notion of accountability, particularly in terms of media understandings of 'holding power to account', which forms the theoretical framework for this study. It is argued that instead of holding governments to account, newspaper practices tend towards acts of surveillance that focus society’s gaze on schools’ performance. Newspapers operate within 'societies of control' (Deleuze, 1995) that use technologies of continual assessment and continual control. Within such societies, reportage is a type of examination of school performance that Foucault (1995) describes as, 'A normalising gaze, a surveillance that makes it possible to qualify, to classify and to punish. It establishes over individuals a visibility through which one differentiates them and judges them' (p. 184). Media practices of top-down modes of vertical accountability, with a gaze focused on schools instead of governments, do not provide support for schools and contribute to a situation where teachers are identified as 'the problem' in education systems. That is, if the media were actually 'holding power to account', government practices would be scrutinised and schools would be supported through a media insistence that governments guarantee human and material resources to support schools; what DarlingHammond (2010) refers to as an 'opportunity to learn standards’ reciprocal accountability system (pp. 279-280).

Following this, the paper outlines the methodological considerations, providing contextual information that helps to understand the socio-economic aspects of the region involved in the study. The paper then outlines how a hybrid form of 'framing theory' (Entman,

\footnotetext{
${ }^{1}$ Since 2008, NAPLAN assessment has been administered to all Australian students in years 3, 5, 7 and 9, testing the four domains of reading, writing, language conventions (spelling, grammar and punctuation) and numeracy (NAP, 2013).
} 
1993) was used to analyse the data, identifying four frames in reference to school performance: those that rank performance such as league tables; frames that decontextualise performance isolating it from school circumstances and levels of funding; frames that residualise government schools; and frames that criticise school management practices. The last of these frames will be the topic of another paper. To conclude, the paper proposes the possibility of reimagining the relationship between the media and schools from one that focuses on top-down vertical accountability practices that function as mechanisms of regulation and focus society's gaze on schools, to that of mutual accountability practices that work towards building community networks of trust, responsibility and collaboration through both horizontal community school relationships and bottom-up modes of accountability.

\section{Theorising accountability}

Historically, the notion of 'accountability' is grounded in political systems and parliamentary democracy (O'Donnell, 2003; Strøm, Müller, \& Bergman, 2003), as well as business models focusing on economics (Wagner, 1989); but interestingly, the trend within GERM is to apply these corporate models to education systems (Sahlberg, 2011). Consequently, schools, educators, and their work are inundated with market-driven accountability practices such as those governed by improvements in 'productivity', 'efficiency', and 'effectiveness' in system 'inputs and outputs'. Conceptually, accountability has at its core a number of 'implicit understandings' (Schedler, 1999), including the notion of being 'held to account' and 'giving an account' (Mulgan, 2003; Ranson, 1986; Wagner, 1989), each of which is underpinned by the condition of ‘answerability’ (Dunsire, 1978; Schedler, 1999). These notions are often identified as ‘core values of democratic governance' (Mulgan, 2003, p. 1). 
The most public of these censures is seen in the media whose normative approach to teacher accountability fixates on actively assessing the 'behaviour of public agents' (Bovens, 2010, p. 946). This approach rarely takes into account institutional arrangements and how they operate, that is, accountability is seen as a virtue rather than a social mechanism (Bovens, 2010). As a virtue, accountability tends to focus on notions of transparency, liability, controllability, responsibility and responsiveness (Koppell, 2005). The theoretical discussion in this section predominantly focuses on media understandings of accountability as identified in the data analysis. In so doing, there is a tendency to focus the discussion on these normative conceptions of accountability, with only a passing mention to the more analytic approaches to accountability such as those outlined by Bovens (2010).

When educators within education systems are 'held to account', this interaction can be defined through relationships of control (Ranson, 1986, 2003), often in hierarchical terms to those higher up in the bureaucracy. This relationship focuses on the public agent 'being accountable’ through a set of standards for accountable actions and behaviours, despite the difficulty with substantively defining these standards (Bovens, 2010). There is also an obligation for the agent to provide 'evidence’ such as assessment data obtained through standardised testing and other accountability policies (Sahlberg, 2011). Ozga (2008) suggests education is increasingly being 'governed by numbers' within an audit society (Power, 1999). These data, based on student examination data, but also on local authority data, school management and financial data, and teacher performance data, tend to provide the information that forms the basis of judgements regarding the actions and performance of schools and educators, in particular as a measure of their outputs or productivity (Ball, 2000). O'Neill (2013) cautions that many 
complexities and difficulties arise when assessment data collected for one purpose are used for performativity and accountability purposes simply because they are readily available (p. 4).

High-accountability agendas, which focus on accountability as a virtue (Bovens, 2010) provide incentives and sanctions for improved performance of both teachers and students (Ball, 2003). However, as Freire (2009) explains there is a tendency towards punishment suggesting, 'We evaluate to punish and almost never to improve teachers' practice. In other words, we evaluate to punish and not to educate' (p. 13). For example, 'name and shame' mentalities that publically stigmatise schools or practices and policies that enable the dismissal of 'bad teachers' based on their performance and student outcomes. Such a focus on outcomes and performance creates a 'distorted view of accountability ... compromis[ing] even further the educational chances of disadvantaged students' (Darling-Hammond, 2004, p. 1058), at times causing teachers or schools to undermine or resist the accountability practices (O'Neill, 2013; Ranson, 2003). Despite this, such data enable bureaucracies to determine the ‘quality’ of the educators and the education systems, which is then often extrapolated to a national level. The account is then judged in relation to performance, thereby shifting accountability to include an evaluation of efficiency (Elliott, 2001) and effectiveness (Power, 1999), and enable the subsequent bureaucratic control of teacher and school performance (Ranson, 2003), as is often seen in the press.

This form of answerability becomes a potentially punitive approach for teachers and schools (Elliott, 2001; Gleeson \& Husbands, 2001). This creates a culture of performativity (Ball, 2003; Lyotard, 1984) where educators are governed by this technology of continuous accountability, where accounts are audited through local, national, and international comparisons to legitimate political action (Nóvoa \& Yariv-Mashal, 2003). In such instances, the notion of 
being held to account also aligns with conceptions of vertical accountability that are hierarchical (West, Mattei, \& Roberts, 2011) or bureaucratic (Darling-Hammond, 2004) and market-driven (Darling-Hammond, 2004; West et al., 2011). These forms of accountability are inextricably linked through their focus on performativity (West et al., 2011).

In the second instance, 'giving an account', which inevitably involves elements of accountability as described above, that focus on accountability as a virtue of the individual agents (Bovens, 2010), also offers additional contextual information. This element of answerability involves 'offer[ing] a narrative which interprets and explains performance ... making intelligible that which may have remained unclear in the facts of a report' (Ranson, 1986, p. 79). Frequently in education and government systems, such narratives are less valued, or not valued at all when compared with the metrics derived from standardised testing, as they are perceived to lack quantitative elements and the necessary rigour to make them useful modes of comparison. This raises question of, 'What counts?' When responding, perspectives that take 'into account' the specific internal and local conditions associated with individual schools and jurisdictions that provide 'rich accountabilities’ (Lingard, Baroutsis, \& Sellar, 2014) are useful; rather than accounts being judged on external conditions and de-contextualised data that are applied carte blanche.

Such an approach provides an alternative perspective on accountability, but one that is not often seen in newspaper reportage. Media organisations often assume they have a pivotal role in ensuring public accountability. For example, Alan Rusbridger (2005, March 9), the outgoing editor-in-chief of The Guardian in the UK, has indicated that the role of the media is to 'challenge power - to hold it to account' (p. 2). Here, the media is understood to undertake the role of 'watchdog' (Finkelstein \& Ricketson, 2012). This notion of 'holding to account' and that 
of a 'watchdog' aligns with understandings of answerability via vertical accountability practices. Schedler (1999) makes the following point, 'The notion of answerability indicates that being accountable to somebody implies the obligation to respond to nasty questions and, vice versa, that holding somebody accountable implies the opportunity to ask uncomfortable questions' (p. 15). This example enables an understanding of the approach taken in the media.

This approach expresses accountability as a social mechanism rather than a virtue (Bovens, 2010). Here, there is acknowledgement that the accountability process does not occur in a void, but rather:

This usually involves not just the provision of information about performance, but also the possibility of debate, of questions by the forum and answers by the actor, and eventually of judgement of the actor by the forum. (Bovens, 2010, p. 951)

When approaching accountability relations from an analytic perspective, Bovens (2010) suggests it is useful to ask a number of additional questions: 'To whom is the account to be rendered?' 'Who should render an account?', and 'Why the actor feels compelled to render account?' (Bovens, 2010, p. 953). Drawing on the media analysis that follows, a simplistic response to these questions from the perspective of the media suggests that the press often express accountability in terms of the collective notion of 'the teachers' or 'the schools', being accountable to institutions or groups such as 'the government' or 'the taxpayers' for reasons relating to the provision of funding. This is a top-down perspective with the media rarely suggesting a bottom-up approach.

A bottom-up approach would acknowledge that accountability is a two-way process, where the school is accountable to the education authorities for their students' learning outcomes and performance, and the education authorities are also accountable to the school (and the child) 
for providing adequate educational resources to make the expected outcomes possible (DarlingHammond, 2010, p. 301; Sahlberg, 2007, p. 155). Darling-Hammond (2010) identifies this reciprocity as 'opportunity to learn standards' and suggests,

Supportive accountability strategies would seek to create a learning system that heightens the probability of good practice and reduces the incidence of poor practice ... [and is] informed by multiple measures of student learning, school practices, and school performance to assess progress. (p. 280)

Good practice is enhanced by systemic practices that provide support for teachers and teaching. That is,

If high-quality teachers lack strong curriculum materials, necessary supplies and equipment, reasonable class sizes, and the opportunity to plan with other teachers to create both appropriate lessons and a coherent curriculum across grades and subject areas, the quality of teaching students experience may be suboptimal, even if the quality of teachers is high.

Many conditions of teaching are out of the control of teachers and depend on the administrative and policy systems in which they work. (Darling-Hammond, 2009, p. 3)

In terms of the media, instead of coverage that rejects teachers' professionalism and school achievements, media organisations can work as 'enablers’, providing support and promoting trust through their reportage of schools and teachers and demanding government provision of resources that support opportunity to learn standards in schools.

Figure 1 provides a visual summary of the developing argument within this paper. The figure outlines the concept of vertical accountability using the institutions and actors associated with this paper. The top-down mode is identified as the focus on test-based accountability practices, while the bottom-up mode relates to the opportunity to learn standards. 
Figure 1: Top-down and bottom-up forms of vertical accountability

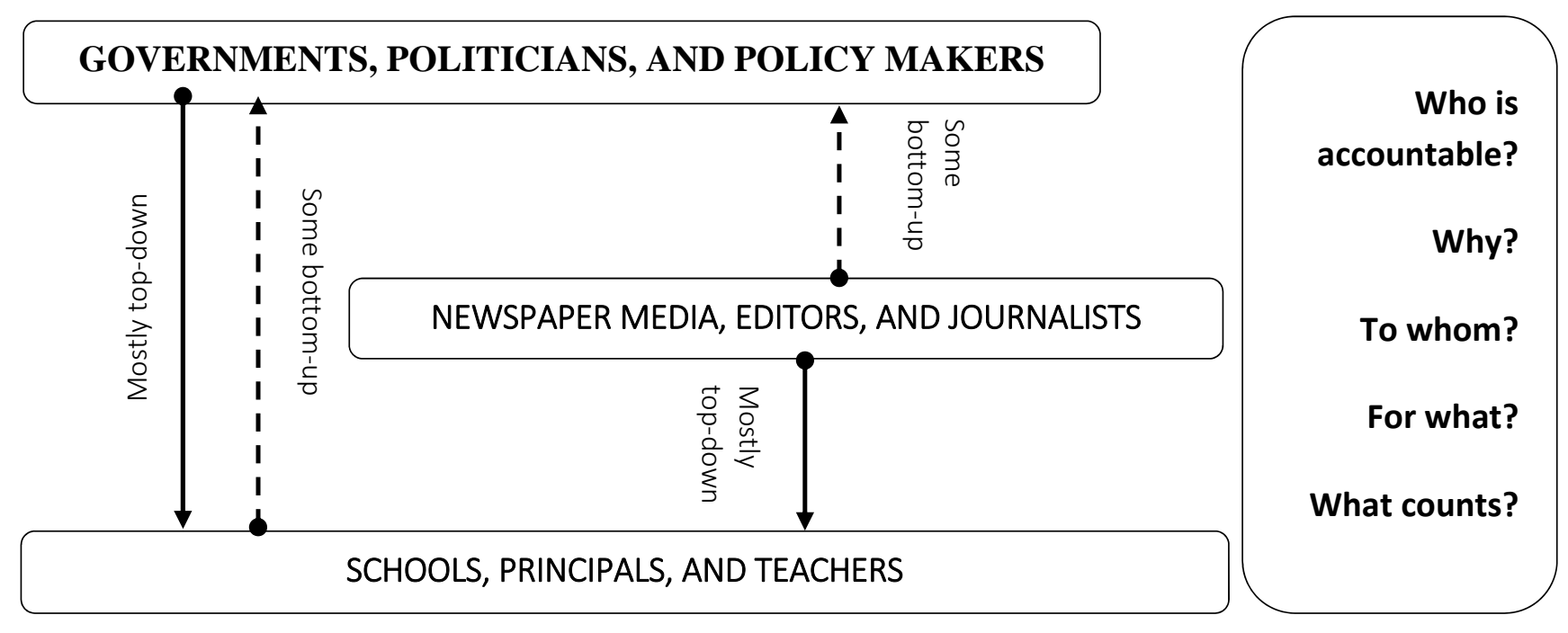

While on occasion, the media do act as intermediaries that place an upward pressure on politicians and policy makers, they often do this with a view towards influencing policy decisions (Birks, 2010), rather than providing the resources required by school to achieve what is expected of them. Similarly, a study by Rawolle (2010) suggests the reverse also occurs and policy makers also attempt to 'steer' the media towards particular frames during policy debates. This is not to say that media reportage is not, at times, scathing of the government (see for example Mockler, 2015). It is just that the media focus in relation to school performance is a downward gaze toward schools and teachers, often reporting on the deficiencies of schools and deriding teachers. Media institutions, by virtue of this perceived role as gatekeepers who are responsible for holding power to account report on the practices of education systems and educators, often editorialising that it is the 'public's right to know'. Unfortunately, this does not hold power, that is, governments to account, but rather often exerts unnecessary pressure on schools and teachers.

By highlighting current reportage in a metropolitan and regional newspaper, this paper posits that the media can play an important role developing school and community networks of 
accountability should the media choose to work with schools as members of the local community. That is, instead of media accounts being limited to comparisons that blame young people, and their teachers, schools, and communities; at their core, bottom-up modes of vertical accountability are able to promote practices of trust, especially in teacher professionals, through community engagement to enhance student learning (O'Neill, 2002; Sahlberg, 2010, 2011; Stobart, 2008).

\section{Methodological considerations}

This paper draws on data gathered for an Australian Research Council funded study titled Pursuing Equity through Rich Accountabilities (PETRA), conducted with a group of eight schools in regional and rural areas of the Wide Bay Burnett area in Queensland, Australia. The project partnered with the Queensland Department of Education, Training and Employment (DETE) who 'identified the region as one seriously impacted by economic restructuring, resulting in a community that had historically been relatively affluent becoming “disadvantaged”' and 'under-researched' compared with disadvantaged communities in urban areas (Lingard et al., 2014, p. 21). The region is identified as one of high disadvantage, being in the lowest quintile (20 per cent) of local government areas identified in the Index of Relative Socio-economic Disadvantage (IRSD) ${ }^{2}$ (ABS - Australian Bureau of Statistics, 2015). The low socio-economic status of the region is also reflected in the Index of Community Socioeducational Advantage (ICSEA) scales, calculated for each school in Australia and made

\footnotetext{
${ }^{2}$ IRSD is a general socio-economic index that summarises a range of information about the economic and social conditions of people and households within an area with a low score generally indicating relatively greater disadvantage (ABS - Australian Bureau of Statistics, 2015).
} 
publically available on the My School website ${ }^{3}$. The ICSEA values for the eight schools in this study, three of which were primary and five secondary, ranged between 886 and 958 in 2012; given the Australian median is 1000, all eight schools are below or well below Australian averages (ACARA, 2015). Additionally, in 2012, the distribution of parental income of the students attending these schools was consistently in the lowest three quartiles, with percentages ranging between 90 to 100 per cent; well above the Australian average distribution of parental income which is 75 per cent (ACARA, 2015). These schools also had high Indigenous populations ranging between seven to 18 per cent of the student population in 2012 (ACARA, 2015).

There are two data-sets associated with this paper: interview data from participants that identify their perceptions of the themes or 'frames' (see below) associated with newspaper reportage about school performance data, and newspaper data that provide examples of this reportage and its framing by the press. The interview data are drawn from a larger data-set of 127 interviews conducted for the PETRA project during 2012-2013. The data are based on semistructured interviews conducted with eight principals and five deputy principals. Of these, seven of the eight principals spoke about their perceptions of the media in their communities, while only one of five deputy principals discussed this aspect of their local communities. The nomenclature used in this paper will refer to the position or role of the individual, for example 'primary principal', and will not identify the schools via pseudonyms or other.

\footnotetext{
${ }^{3}$ ICSEA is a scale of socio-educational advantage. The values are calculated on a scale which has a median of 1000 and a standard deviation of 100. ICSEA values typically range from approximately 500 (representing extremely educationally disadvantaged backgrounds) to about 1300 (representing schools with students with very educationally advantaged backgrounds) (ACARA, 2014).
} 
Another data-set draws on newspaper reports from The Courier Mail, a Queensland newspaper servicing metropolitan and regional areas of the state; and the NewsMail, a regional Queensland newspaper drawing on reportage in Bundaberg and surrounding areas, part of the Wide Bay Burnett region. The Courier Mail is owned by Rupert Murdoch’s News Corporation Australia, while the NewsMail is an APN News \& Media Limited newspaper (with 14.9 per cent ownership by News Corporation). The Factiva database was used to conduct keyword searches using the terms: 'NAPLAN and school', the 'and' being a Boolean operator. This was for a six year period between 2009 and 2014, a duration that encompasses the project time frame. Table 1 summarises the frequency of the total articles referring to NAPLAN and those specifically addressing school and state performance. There appeared to be a steady rate of reportage on school performance by the NewsMail; however, The Courier Mail's rate of reportage on school performance varied with the largest number of school and state performance articles being written in 2012. The nomenclature used in this paper will refer to The Courier Mail as a metropolitan newspaper and the NewsMail as a regional newspaper.

Table 1: Overview of newspaper articles address school performance

\begin{tabular}{|c|c|c|c|c|c|c|c|c|c|}
\hline \multirow[b]{2}{*}{ Newspaper } & \multicolumn{7}{|c|}{ School or Queensland performance } & \multirow{2}{*}{$\begin{array}{c}\text { Total } \\
\text { articles } \\
\text { on } \\
\text { NAPLAN } \\
\end{array}$} & \multirow{2}{*}{$\begin{array}{c}\text { Percentage of } \\
\text { articles on } \\
\text { school } \\
\text { performance }\end{array}$} \\
\hline & 2009 & 2010 & 2011 & 2012 & 2013 & 2014 & Total & & \\
\hline $\begin{array}{l}\text { The } \\
\text { Courier } \\
\text { Mail }\end{array}$ & 15 & 11 & 6 & 24 & 9 & 5 & 70 & 323 & $22 \%$ \\
\hline NewsMail & 3 & 2 & 3 & 2 & 3 & 3 & 16 & 53 & $30 \%$ \\
\hline
\end{tabular}

The data were analysed using the notion of 'framing' (Entman, 1993, 2007; Iyengar, 1991). This relates to the how the media 'frames' the stories relating to school performance. Entman (1993) describes framing theory as, 
Essentially involve[ing] selection and salience. To frame is to select some aspects of a perceived reality and make them more salient in a communicating text, in such a way as to promote a particular problem definition, causal interpretation, moral evaluation, and/or treatment recommendation for the item described. (p. 52)

Using Foucault's (1980) notion of 'regimes of truth', we see that such frames position media organisations as being able to determine 'what counts as true' and thereby circulating a 'general politics of truth' (p. 131). Elsewhere, Entman (2003) raises the notion of frame parity, stating,

To reach frame parity, the news must offer a counterframe that puts together a complete alternative narrative ... possessing as much magnitude and resonance as the [dominant frame]. Availing themselves of such diverse, clashing, and equally well-developed understandings, a democratic citizenry can in theory freely and intelligently choose. As already suggested, frame parity is the exception, not the rule. (p. 418)

Unfortunately, frame parity rarely occurs in the media, often leaving society with a particular version of ‘truth' and 'reality'. Goode (2009) suggests ‘journalism is in no small measure a craft of re-telling stories rather than simply disclosing them' (p. 1290). Consequently, it should not be assumed that the press are neutral in their news making (Blackmore \& Thomson, 2004; Mills \& Keddie, 2010; Thomson, Blackmore, Sachs, \& Tregenza, 2003). This can be problematic in that the newspaper representations inform the readers and construct particular realities and truths about schools.

While this methodological tool is usually applied to media texts, framing theory has been expanded to include educators' narratives of their interpretations of media frames that are used in reportage about their schools. This is similar to the precedence that Altheide (1987) established when he proposed a combination of elements of ethnographic research with a content analysis. In so doing, the narratives and observations of the participants guided the inquiry and identified the 
parameters. Similarly, Kamberelis and Dimitriadis (2005) suggest researchers are encouraged to eclectically adapt, borrow, combine, work and rework existing methodological frameworks to suit a study (p. 18).

This methodological adaptation was advantageous in this project as it meant that participants' first-hand perspectives were used as the starting point to guide the data collection and identify keywords that could be used to search the Factiva database. This was a mechanism for containing the data gathering process to that which was likely to yield manageable quantities of articles that were relevant to the study. However, there was also some methodological disadvantage to this process as this restricted the parameters of the inquiry, and potentially, additional frames may have been overlooked. This, however, was not detrimental to the study, quite the opposite, in that the focus of this study was to enable the educators' voice through the use of their narratives. Therefore, the methodological approach privileged this voice. Within the area of school performance, the school leaders identified four main frames: ranking school performance; frames that de-contextualise school data by focusing on only test-based performances; frames that residualise government schools through unfavourable reporting about public schools; and frames that criticise school-based management practices. Table 2 summarises the frequency and distribution of these frames in both the metropolitan and regional newspapers.

Table 2: Frequency and distribution of media frames in newspaper reportage

\begin{tabular}{|l|c|c|c|}
\hline Media frames about school performance & $\begin{array}{c}\text { The Courier } \\
\text { Mail (n=70) }\end{array}$ & $\begin{array}{c}\text { NewsMail } \\
(\mathrm{n}=16)\end{array}$ & $\begin{array}{c}\text { Total } \\
(\mathrm{n}=86)\end{array}$ \\
\hline Ranking school performance & $40 \%$ & $50 \%$ & $42 \%$ \\
\hline Comparing school performance & $24 \%$ & $13 \%$ & $22 \%$ \\
\hline $\begin{array}{l}\text { Comparing performance of government } \\
\text { and non-government schools }\end{array}$ & $31 \%$ & $6 \%$ & $27 \%$ \\
\hline
\end{tabular}


For both newspapers, the largest number of articles used frames that ranked and compared school performance. This was followed by the metropolitan newspaper's focus on comparing the performance of government and non-government school performance, which was not evident in the regional newspaper. However, the regional newspaper focused on criticisms of school management practices such as funding, student attendance rates, and behaviour management, a frame that was not as evident in the metropolitan newspaper within the context of school performance and NAPLAN. Given that there was limited evidence about frames relating to school management practices, and the anomaly between reportage in metropolitan and regional newspaper, it was decided that aspect of the data would benefit from a more detailed analysis in another paper.

\section{Framing performance using comparison data}

The NAPLAN data, derived from high-stakes testing, are an example of narrow data-sets being used to gauge school performance. Such practices are often undertaken within the context of global policy rhetoric about 'failing schools' that Berliner and Biddle (1995) identify as a 'manufactured crisis'. In Australia, NAPLAN test results are published on the My School website identifying amongst others, the 'failing' schools, based on statistical information about the schools. The My School website, a tool established by the Australian Government, is often applauded in the press (Baroutsis, 2014) as providing the necessary information for the consumers in the education 'market-place' through the collation of 'comparison and commodification’ data (Ball, 2000). However, the My School website and the consequent newspaper reportage on these data could thus be seen as a 'constructed artifice' (Ball, 1997, 
2000) outlining certain truth claims over others. Additionally, it might be seen as a 'fabrication' as its production is based solely on one version of representation (Ball, 2003), derived mostly from quantitative measurement data. These data are then 'packaged' (Franklin, 2004), or framed, in particular ways and presented in the press. The practice of comparison acts as a mechanism of control that publicly shames the 'bad' schools and seemingly encapsulates the perceived worth of schools, the teachers and the students through this unitary measure. However, it could be argued that this approach does not take into account the individual school contexts that are able to provide equally useful and rich school-based narrative accounts of the specifications of each individual school.

The media framing of 'school performance' acts as a mode of regulation and scrutiny that is focused on 'holding schools to account' using mostly top-down accountability. The participants' perceptions of how the regional and metropolitan newspapers framed school performance were understood through reportage that focused on standardised test data such NAPLAN. The newspaper framing of school performance included: ranking performance using league tables; decontextualising performance and isolating only certain aspects as aligning with success; and frames that residualise government schools.

\section{Frames that rank performance}

Many of the participants in this study shared their negative perceptions and experiences of the use of NAPLAN data by the press. While the school leaders found the NAPLAN results useful, suggesting they were tools for 'reflection' (deputy principal) and a means of providing 'feedback' (secondary principal) for 'school improvement' (secondary principal), they were unanimously opposed to the media conversion of these data into league tables. A secondary principal indicated: 'They're not meant to be league tables. That list that came out in The 
Courier Mail was just diabolical'. Another secondary principal suggested, 'There's no need for league tables for comparisons' with a deputy principal adding, 'Should it be used to rank schools or compare schools? Definitely not! No! It shouldn't be happening'. As another primary principal indicated, 'Principals have to be prepared for the fallout if it's a bad result', while a secondary principal added, 'Because whatever is in the paper, it affects us'. The potential for reputational damage to school following negative NAPLAN reportage is therefore increased.

The study found that metropolitan newspapers, rather than regional, published stories that focused on rank order lists of NAPLAN data. For example in 2012, The Courier Mail published the Queensland Schools Guide, which claimed to provide an 'unprecedented look at school performance’, allowing every parent to ‘compare’ (Chilcott \& Davies, 2012, p. 1). Such reportage amplifies measurement and comparison practices as modes of top-down, vertical accountability that publically scrutinise schools and make visible their NAPLAN performance. This newspaper practice tended to create numerous 'top 10' lists, where the salient features of the news foregrounded school performance. This included a somewhat positive rank order of Queensland's 50 top schools based on year 3, 5 and 7 NAPLAN data between 2008 and 2011 (The Courier Mail, 2012c). However, other lists such as the 10 most improved schools based on year 3 (2008-2009) and year 5 (2010-2011) NAPLAN data (The Courier Mail, 2012b) had undertones of polite ridicule when addressing this change in results. Another series of reports provided comparative lists that isolated the performance of some Queensland schools when compared to the national performance rankings on NAPLAN (Chilcott, 2010a, 2011b, 2012e) and that of other states and territories (Chilcott, Brumpton, \& Davies, 2012). The claims here were that even the top performing students in Queensland are lagging behind students in 'similar schools' in other states and territories (Chilcott, Brumpton, \& Davies, 2012, p. 12). Perhaps most 
disturbing were the league tables that compared the government and non-government schools’ performance and the socio-economic status of the community as they contribute to the public debate that frames government schools in low socio-economic areas in negative terms, potentially contributing to the residualisation of these schools (see section below). For example, one report compared the average net recurrent income per student in 2011 of government schools with private schools (Chilcott, Kidd, \& McKenna, 2013), while another listed high-performing government and private schools based on student scores above the national average (Chilcott, Chudleigh, \& Clarke, 2009). In other examples, schools were ranked according to student performance based on the ICSEA scores of their residential address (Chilcott, 2012b), as well as the performance of regional schools including Indigenous communities (Chilcott, Cane, \& Cornish, 2012).

The problem with simplistic analysis of data such as that found in league tables is that ‘creative accounting’ practices can take hold where data could be manipulated to say 'what you like' as there is always a way of 'frustrating' the conventional rules of interpretation while 'appearing to comply’(Power, 1999). Berliner and Biddle (1995) add, perhaps in less menacing terms to the above, that when more detailed forms of analysis are carried out on the same data there are increases, sharp reductions or even the reversal of the findings when compared to the findings in the simplistic analysis (p. 159). They explain that this is because a more complex analysis would take into account the effects of other crucial factors that a simplistic analysis does not. Additionally, Wu (2010) suggests that often the 'statistical complexity [of the data] prevents the non-technical stakeholders from fully appreciating the caveats in the results, leading to misinterpretation, over-interpretation and even worse, making inappropriate policy decisions’ (p. 24). Finally, Sahlberg (2007), when referring to international data comparisons, explains the 
limited usefulness of comparative data that simply look at ranked tables. This is because such comparisons fail to take into account the underlying characteristics that may explain the comparative performance of schools. Each of these considerations suggests that league tables and rank ordered lists are an ineffective means of comparison and not particularly helpful for school reform and improvement.

\section{Frames that de-contextualising performance}

The quantitative NAPLAN data were often used in isolation and thereby were de-contextualised, failing to take into account the specificity and uniqueness of individual schools. A primary principal indicated, 'NAPLAN, where it's published and given it is public information ... It is becoming more and more challenging when we get those sorts of information used just in isolation, without actually being part of the school'. Due care is needed when reducing complex education issues into media sound-bites that forge only simplistic understandings of schools and communities (Baroutsis, 2014).

Often, an individual school is not the primary focus of these data; rather, all school results are in the database for the purposes of comparison. The schools become 'collateral damage’ (Nichols \& Berliner, 2007) or incidental casualties in the drive to measure and compare performance in schools. The focus on accountability and performativity often brings with it 'public humiliation’ (Nichols \& Berliner, 2007) for 'unsuccessful' schools that may result in a distortion of school practices so as to avoid further embarrassment (Ball, 2003). This devalues individual low-achieving schools, most of which are serving poor and disadvantaged communities.

Occasionally, both the regional (see for example, Thompson, 2011) and metropolitan newspapers (see for example, Chilcott, 2012c; Kidd, 2012; The Courier Mail, 2012a) framed a 
story around a particular school that had shown improvement in NAPLAN testing where the data was not de-contextualised. A headline in the regional newspaper read, Pupils soar in NAPLAN tests, and reported on the achievements of Gin Gin High School, stating, 'out of 43 schools in the region, the year 9s topped the region in persuasive writing ...' (Thompson, 2011, p. 8). In each article, the first salient point always identified school performance in relation to quantitative data, the report then quoted the principal who elaborated. A recurring theme amongst the participants in this study was that their schools are successful in ways that are not captured by standardised test data or the media coverage of NAPLAN performance. For example, there is no measure regarding successes in sport or music, nor those of the individual students who attain their 'personal best' in their classwork attendance. Interestingly, none of the principals from the above reports identified their school's achievements other than on NAPLAN; or if they did, this was not selected as part of the news report. As well as the 'investigative-style' reports outlined above, some schools produce their own public relations style news reports and submit these to the newspaper. These reports are characterised within the 'newsletter-style' genre that outline the students' and school's many additional achievements, but are generally only picked up by local newspaper and buried in the back pages (see for example, NewsMail, 2009, 2012). These examples framed school performance around sporting and cultural achievements, as well as academic performance.

The principals often associated school performance and improvement with the level of funding they received, however, the press often did not. A secondary principal made a comment about another school in their region suggesting:

I know if they had the money, then they would have shown significant improvement and you get the good news stories on front page of the paper and that helps the community and the perception of what is a good school by parents in the community. 
This is one example of how the press can frame school performance through opportunity to learn standards that utilise bottom-up accountability, thereby holding governments to account and challenging them regarding funding and resourcing to schools. For example, a report in the regional newspaper indicated that the My School website 'revealed surprising financial gaps between regional, city and private schools in the Bundaberg region' (Marsh, 2011, p. 7), but the reporter is reconciled to accept this rather than challenging the inequality and inequities in funding. Elsewhere, the metropolitan newspaper goes so far as to congratulate the Queensland Government on their reforms including an 'increased education budget' (see for example, The Courier Mail, 2013, p. 22). Only one instance of reportage identified a counter-frame and demonstrated bottom-up accountability. The Courier Mail's school reporter, writes Poor kids suffer in political squabble over school funds (Chilcott, 2013a), suggesting that 'poverty should not impede opportunity' and that politics was dictating the outcomes for the state's most disadvantaged children (p. 18). In her report, she noted how she challenged the then Education Minister about the government's decision to cease redistributive funding to low socio-economic schools. In other reports such as System fails Indigenous pupils (Chilcott, 2012d) or Pressure on top schools - Review questions funding (Chilcott, 2011a) there is reportage on the topic but no bottom-up accountability is exerted on the government about resourcing to improve the situation. In each of these examples, quotes are selected from the Education Minister who works towards justifying the situation. Additionally, the opinion pieces selected for publication (see for example, Bantick, 2010; King, 2010) in the metropolitan newspaper support performance testing and blame teachers, rather than challenging governments on resourcing, as the cause of poor performance (also see Baroutsis, 2014). The newspaper data from this study suggest that the media seldom advocates on the behalf of the government school. 


\section{Frames that residualise government schools}

There has been a decline in enrolment numbers in government schools, a trend evident in the last decade where non-government schools now accommodate 34.9 per cent of the student population, an increase of 7.1 per cent (ABS - Australian Bureau of Statistics, 2004, 2014). A secondary school principal spoke of the school's declining enrolments:

We don't get their figures, but all I can say is this school is pulling a number of kids outside the catchment. This year is a worrying with our year $8 \mathrm{~s}$... [They go to] private schools and independents, who run buses past our door.

Another secondary school principal outside of the Bundaberg area indicated:

I guess one of my aims as a principal of this school is to offer a quality of education where parents don't have to send their kids into Bundaberg to access any private form of schooling. But that whatever their needs are can be met here, whatever opportunities they need can be facilitated here.

Despite such attempts to retain students and improve enrolments, residualisation is occurring in this region. The process of residualisation refers to situations where low socio-economic schools in less privileged areas, such as Wide Bay Burnett in Queensland, are drained of their high achieving and most able students (Lamb, 2007, p. 21). As they leave government schools to attend schools in the private sector, a low-achieving 'residue' is created in the government schools, and this is reflected, but not acknowledged in the performance data. Consequently, these schools' performance is affected, and they may be further exposed to 'public haranguing' through 'published ranking systems' (Windle, 2009, p. 242) such as those found in the media league tables. A primary principal indicated: 
It really residualises our schools and we have you know the brighter intelligent wealthier families moving to those schools and the kids that can't move basically, or the families that can't, they stay in schools where the data may not be that good, that reflects it.

The principals generally attributed the departure of their high-achieving students to parental perceptions about government schooling.

Some principals indicated their opinion that the decisions to withdraw students or not enrol them in government schools was based on publicly available data on school performance that often suggests private school students perform better in NAPLAN (see for example, Chilcott, 2012a; The Courier Mail, 2012d). Such reports were mainly found in the metropolitan newspaper, with one report suggesting government schools 'matched' the performance of their private counterparts (Chilcott, 2013b, p. 10). Both metropolitan and regional newspapers reported on decline of enrolments in government schools. The metropolitan newspaper outlined the number of enrolments in each sector and suggested, 'Publicity around national test results is being blamed for a drop in state school enrolment growth this year, as the Catholic sector continues to climb’ (Chilcott, 2010b, p. 4). The regional newspaper also cited similar statistics and quoted the Education Minister as saying, 'Parents believed their children would get a better education at a private school' (Emery, 2011, p. 6). Overall, the reportage is perhaps more balanced in regional newspapers that tend to report the successful school performance of both government (Thompson, 2011) and private schools (Emery, 2009; Emery \& Derry, 2010).

As a consequence of the residualisation process, government schools face greater instability of potentially reduced funding, greater government interference and compromised educational equity (Windle, 2009, p. 242). The marketisation of schools and the consequent residualisation of government schooling has many education figures being quoted in the press 'urging caution around parents using results and analysis ... to compare schools particularly 
“similar school” comparisons which they warn can be misleading' (Chilcott et al., 2013, p. 8). However, again, the media has missed an opportunity to exercise bottom-up accountability and challenge governments on their practices that residualise government schools.

\section{Conclusions: Reimagining school and media practices}

While it is difficult to argue against the notion of accountability in education, this paper advocates that there ought to be multiple accountability practices in addition to vertical, topdown, test-based modes of accountability. The perceptions and experiences of those in this regional community were that the newspaper media are by and large detrimental to government schools where they publish the negative stories in an attempt to hold schools 'to account'. Such perceptions were also expressed in a recent report on media practices in Australia that indicated there were 'numerous instances of the media doing unjustified harm to people, and the failure of the existing regulatory systems to hold the media to account for these harms' (Finkelstein \& Ricketson, 2012, p. 20). In focusing on the negative, media texts may 'naturalise' these harmful understandings of schools, teachers and students, thereby projecting a 'taken-for-granted' or ‘commonsensical’ perception of what happens in schools (Baroutsis, 2015).

Of the themes identified by the participants, the newspaper analysis found evidence of reportage using each of the four frames, three of which for the basis of this paper. First, the metropolitan newspaper consistently framed school performance negatively through rank order lists and league tables, while the regional newspaper did not participate in this accountability practice. Secondly, both metropolitan and regional newspapers framed school performance in a de-contextualised manner that predominantly referred to school and state performance on standardised tests, without contextualising these in terms of school resourcing or communities served. Finally, while both the metropolitan and regional newspapers were found to frame 
reportage in ways that contribute to the residualisation of government schools, the regional newspaper had a more balanced approach to reportage on government and non-government schools and highlighted the successes and shortcomings in both systems.

The media in this study showed no inclination towards reportage that interrogated the Australian Government's policy perspectives related to NAPLAN testing, school performance and accountability. Olssen, Codd, and O'Neill (2004) suggest it is only through a 'process of interrogation' that policy can be 'rendered intelligible' (p. 4). Additionally, there was no evidence of media reportage that contested or criticised the establishment for their NAPLAN policies that acted as technologies to gauge school performance and monitor accountability. From a policy enactment perspective, the media, in this instance, have not engaged in reportage practices of interrogation or contestation, rather assumed the role of reinforcing the Australian Government's policies about NAPLAN and top-down, test-based modes of educational accountability. The media has failed to adequately hold the system and governments to account for, amongst other things, the opportunity to learn standards; thereby releasing the system and politicians of their obligation to provide substantial material educational resources as part of a mutual accountability process. This is problematic given that, as Ball, Braun, and Maguire (2012) suggest, 'policies are enacted in material conditions' and as such, these media practices do not recognise the significance of the contextual dimensions of policy enactment such as material contexts including budgets and staffing in individual schools, and only take into account homogenised notions of external contexts drawn from rank orders and league tables (p. 21).

Instead of the current situation where media practices focus society's gaze on schools, framing school performance in terms of comparisons, reportage can be reimagined through a focus on 'rich' accounts that can be drawn from school-based narratives. Narratives are better 
able to contextualise schools’ performance giving a better understanding of schools and the contextual dimensions of policy enactment. In particular, through the use of media practices that incorporate bottom-up accountability, challenging governments to meet opportunity to learn standards and enabling schools to meet high educational outcomes for all students. This approach of 'rich', narrative-based accounts provides a more balanced perspective of schools and works towards developing 'counter-frames' and encouraging the media to strive towards frame parity. Additionally, it does not de-value or de-contextualise the schools concerned by using only comparison data; and ideally, builds trust between school and their communities. Such practices draw on more democratic understandings of accountability engaged in 'democratic conversations’ and 'participatory democracy' (Ryan, 2005, p. 537).

The regional school principals have already started such conversations with a regional newspaper editor to get positive, narrative-based stories about their schools into the local media and have been experiencing some success with this community-based practice. In saying this, it is acknowledged that such relationships between principals and newspaper editors are more likely to occur in regional communities with local newspapers as they are smaller and more intimate communities, while larger newspapers tend to focus on elites. Consequently, there is hope to reimagine accountability practices between schools and their communities as mutual and reciprocal; where schools are encouraged to 'give accounts' through school-based narratives that augment and enhance comparison data; and the media challenge governments regarding their provisions to schools. As such, media practices will not simply reinforce the dominant practices of accountability, but interrogate and contest policies and practices associated with school performance. 


\section{References}

ABS - Australian Bureau of Statistics. (2004). 4221.0 - Schools, Australia (Reissue), 2004 Retrieved 22 April, 2015, from http://www.abs.gov.au/AUSSTATS/abs@.nsf/allprimarymainfeatures/0F3FE57C171746 77CA25711D000DF0F4?opendocument

ABS - Australian Bureau of Statistics. (2014). 4221.0 - Schools, Australia, 2014. Retrieved 22 April, 2015, from http://www.abs.gov.au/AUSSTATS/abs@.nsf/allprimarymainfeatures/9448F2F814FA03 11CA2579C700118E2D?opendocument

ABS - Australian Bureau of Statistics. (2015). 2033.0.55.001 - Census of Population and Housing: Socio-Economic Indexes for Areas (SEIFA), Australia, 2011. Retrieved 12 February, 2015, from http://www.abs.gov.au/AUSSTATS/abs@.nsf/DetailsPage/2033.0.55.0012011?OpenDoc ument

ACARA. (2014). Guide to understanding 2013 Index of Community Socio-educational Advantage (ICSEA) values. Retrieved 12 February, 2015, from http://www.acara.edu.au/verve/_resources/Guide_to_understanding_2013_ICSEA_values .pdf

ACARA. (2015). My School. Retrieved 12 February, 2015, from http://www.myschool.edu.au

Altheide, D. L. (1987). Reflections: Ethnographic Content Analysis. Qualitative Sociology, 10(1), 65-77.

Apple, M. W. (2006). Educating the 'right' way: Markets, standards, God, and inequality (2 ed.). New York: Routledge.

Ball, S. J. (1997). Good school/bad school: Paradox and fabrication. British Journal of Sociology of Education, 18(3), 317-336.

Ball, S. J. (2000). Performativities and fabrications in the education economy: Towards the performative society. Australian Educational Researcher, 27(2), 1-23.

Ball, S. J. (2003). The teacher's soul and the terrors of performativity. Journal of Education Policy, 18(2), 215-228.

Ball, S. J., Braun, A., \& Maguire, M. (2012). How schools do policy: Policy enactments in secondary schools. New York: Routledge.

Bantick, C. (2010, 17 June). NAPLAN tests show need for improved teaching. The Courier Mail, p. 43.

Baroutsis, A. (2014). Troubling news: Challenging politics, perceptions and practices of newspaper constructions of teachers. (Doctor of Philosophy), The University of Queensland, Brisbane.

Baroutsis, A. (2015). Symbolic power, politics and teachers. Discourse, Studies in Cultural Politics of Education, 36(4). doi: 10.1080/01596306.2015.1011866

Berliner, D. C., \& Biddle, B. J. (1995). The manufactured crisis: Myths, frauds, and the attack on America's public schools. New York: Longman.

Birks, J. (2010). The democratic role of campaign journalism. Journalism Practice, 4(2), 208223. 
Blackmore, J., \& Thomson, P. (2004). Just 'good and bad news'? Disciplinary imaginaries of head teachers in Australian and English print media. Journal of Education Policy, 19(3), 301-320.

Bovens, M. (2010). Two concepts of accountability: Accountability as a virtue and as a mechanism. West European Politics, 33(5), 946-967.

Braun, A., Maguire, M., \& Ball, S. J. (2010). Policy enactments in the UK secondary school: Examining policy, practice and school positioning. Journal of Education Policy, 25(4), 547-560.

Chilcott, T. (2010a, 11 September). NAPLAN results no cause for celebration. The Courier Mail, p. 4.

Chilcott, T. (2010b, 15 February). State school growth drop - Test results blamed for fall. The Courier Mail, p. 4.

Chilcott, T. (2011a, 1 September). Pressure on top schools - Review questions funding. The Courier Mail, p. 2.

Chilcott, T. (2011b, 10 September). State learning curve lifts but still lagging. The Courier Mail, p. 2.

Chilcott, T. (2012a, 30 July). Highest fees add up to top scores. The Courier Mail, p. 6.

Chilcott, T. (2012b, 2 May). Parents play big part in educational advantage. The Courier Mail, p. 9.

Chilcott, T. (2012c, 2 May). School stamps out postcode past. The Courier Mail, p. 9.

Chilcott, T. (2012d, 19 September). System fails indigenous pupils. The Courier Mail, p. 9.

Chilcott, T. (2012e, 15 September). Towards the bottom of the class but gap is narrowing. The Courier Mail, p. 4.

Chilcott, T. (2013a, 29 April). Poor kids suffer in political squabble over school funds. The Courier Mail, p. 18.

Chilcott, T. (2013b, 16 September). State primaries teach elite schools a lesson. The Courier Mail, p. 10.

Chilcott, T., Brumpton, H., \& Davies, A. (2012, 25 February). Our students closing the gap on education. The Courier Mail, p. 12.

Chilcott, T., Cane, K., \& Cornish, L. (2012, 1 May). Indigenous education shows gains. The Courier Mail, p. 5.

Chilcott, T., Chudleigh, J., \& Clarke, W. (2009, 8 August). Private schools top the class. The Courier Mail, p. 2.

Chilcott, T., \& Davies, A. (2012, 30 April). Top marks - Ultimate online guide rates your school. The Courier Mail, p. 1.

Chilcott, T., Kidd, R., \& McKenna, K. (2013, 14 March). We're slipping behind in NAPLAN rankings. The Courier Mail, p. 8.

Cohen, J. L. (2010). Teachers in the news: A critical analysis of one US newspaper's discourse on education, 2006-2007. Discourse: Studies in the Cultural Politics of Education, 31(1), 105-119.

Connell, R. (2013). The neoliberal cascade and education: An essay on the market agenda and its consequences. Critical Studies in Education, 54(2), 99-112.

Darling-Hammond, L. (2004). Standards, accountability, and school reform. Teachers College Record, 106(6), 1047-1085.

Darling-Hammond, L. (2009). Recognising and enhancing teacher effectiveness. The International Journal of Educational and Psychological Assessment, 3(Dec), 1-24. 
Darling-Hammond, L. (2010). The flat world and education: How America's commitment to equity will determine our future. New York: Teachers College Press.

DEEWR. (2008). Melbourne Declaration on the Educational Goals for Young People. Canberra: Ministerial Council on Education, Employment, Training and Youth Affairs.

Deleuze, G. (1995). Negotiations 1972-1990 (M. Joughin, Trans.). New York: Columbia University Press.

Dunsire, A. (1978). Control in a bureaucracy: The execution process (Vol. 2). Oxford, UK: Martin Robertson.

Elliott, J. (2001). Characteristics of performative cultures: Their central paradoxes and imitations as resources for education reform. In D. Gleeson \& C. Husbands (Eds.), The performing school: Managing, teaching and learning in a performance culture (pp. 192-209). London: Routledge/Falmer.

Elstad, E. (2009). Schools which are named, shamed and blamed by the media: school accountability in Norway. Educational Assessment, Evaluation and Accountability, 21(2), 173-189.

Emery, L. (2009, 16 September). Education. NewsMail, p. 5.

Emery, L. (2011, 16 February). More parents opting for private over public. NewsMail, p. 6.

Emery, L., \& Derry, M. (2010, 29 January). Our schools wary about My School of thought. NewsMail, p. 4.

Entman, R. M. (1993). Framing: Toward clarification of a fractured paradigm. Journal of Communication, 43(4), 51-58.

Entman, R. M. (2003). Cascading activation: Contesting the White House's frame after 9/11. Political Communication, 20(4), 415-432.

Entman, R. M. (2007). Framing bias: Media in the distribution of power. Journal of Communication, 57(1), 163-173.

Finkelstein, R., \& Ricketson, M. (2012). Report of the independent inquiry into the media and media regulation. Canberra, AU: Department of Broadband, Communications and the Digital Economy.

Foucault, M. (1980). Truth and power (C. Gordon, L. Marshall, J. Mepham \& K. Soper, Trans.). In C. Gordon (Ed.), Power/knowledge: Selected interviews and other writings, 1972-1977 (pp. 109-133). New York: Vintage Books.

Foucault, M. (1995). Discipline and punish: The birth of the prison (A. Sheridan, Trans. 2 ed.). New York: Vintage Books.

Franklin, B. (2004). Packaging politics: Political communications in Britain's media democracy (2 ed.). London: Arnold.

Freire, P. (2009). Teachers as cultural workers: Letters to those who dare teach (D. Macedo, D. Koike \& A. Oliveira, Trans. expanded ed.). New York: Westview Press.

Gleeson, D., \& Husbands, C. (Eds.). (2001). The performing school: Managing, teaching and learning in a performance culture. London: RoutledgeFalmer.

Goode, L. (2009). Social news, citizen journalism and democracy. New Media \& Society, 11(8), 1287-1305.

Gutiérrez, K. D., Asato, J., Santos, M., \& Gotanda, N. (2002). Backlash pedagogy: Language and culture and the politics of reform. Review of Education, Pedagogy, and Cultural Studies, 24(4), 335-351.

Hattam, R., Prosser, B., \& Brady, K. (2009). Revolution or backlash? The mediatisation of education policy in Australia. Critical Studies in Education, 50 (2), 159-172. 
Iyengar, S. (1991). Is anyone responsible? How television frames political issues. Chicago: University of Chicago Press.

Kamberelis, G., \& Dimitriadis, G. (2005). On qualitative inquiry: Approaches to language and literacy research. New York: Teachers College Press.

Kidd, R. (2012, 15 September). Glenala State High School. The Courier Mail, p. 4.

King, M. (2010, 15 May). Tests are the answer. The Courier Mail, p. 70.

Koppell, J. G. (2005). Pathologies of accountability: ICANN and the challenge of 'multiple accountabilities disorder'. Public Administration Review, 65(1), 94-108.

Lamb, S. (2007). School reform and inequality in urban Australia: A case of residualising the poor. In R. Teese, S. Lamb \& M. Duru-Bellat (Eds.), International studies in educational inequality, theory and policy (Vol. 3, pp. 1-38). The Netherlands: Springer.

Lingard, B. (2010). Policy borrowing, policy learning: Testing times in Australian schooling. Critical Studies in Education, 51(2), 129-147.

Lingard, B. (2011). Policy as numbers: Ac/counting for educational research. The Australian Educational Researcher, 38(4), 355-382.

Lingard, B., Baroutsis, A., \& Sellar, S. (2014). Learning Commission Report: Connecting schools with communities. Brisbane: The University of Queensland.

Lipman, P. (2009). Paradoxes of teaching in neo-liberal times: Education 'reform' in Chicago. In S. Gewirtz, P. Mahony, I. Hextall \& A. Cribb (Eds.), Changing teacher professionalism: International trends, challenges, and ways forward (pp. 68-80). Milton Park, UK: Routledge.

Lyotard, J.-F. (1984). The postmodern condition: A report on knowledge (G. Benninton \& B. Massouri, Trans.). Minneapolis, MN: University of Minnesota Press.

Marsh, V. (2011, 5 March). My School site revamp. NewsMail, p. 7.

Mills, M., \& Keddie, A. (2010). Cultural reductionism and the media: Polarising discourses around schools, violence and masculinity in an age of terror. Oxford Review of Education, 36(4), 427-444.

Mockler, N. (2013). Reporting the 'education revolution': MySchool.edu.au in the print media,. Discourse: Studies in the Cultural Politics of Education, 34(1), 1-16.

Mockler, N. (2015). NAPLAN and the 'problem frame': Exploring representations of NAPLAN in the print media, 2010-2013. In B. Lingard, S. Sellar \& G. Thompson (Eds.), Assessing National Testing in Australia. Abingdon: Routledge.

Mulgan, R. (2003). Holding power to account: Accountability in modern democracies. New York: Palgrave Macmillan.

NAP. (2013). NAPLAN. Retrieved 10 March, 2015, from http://www.nap.edu.au/naplan/naplan.html

NewsMail. (2009, 2 December). Busy year ends for Childers students. NewsMail, p. 24.

NewsMail. (2012, 29 May). North shines in all areas. NewsMail, p. 23.

Nichols, S., \& Berliner, D. C. (2007). Collateral damage: How high stakes testing corrupts America's schools. Cambridge, MA: Harvard Education Press.

Nóvoa, A., \& Yariv-Mashal, T. (2003). Comparative research in education: A mode of governance or a historical journey? Comparative Education, 39(4), 423-438.

O'Donnell, G. (2003). Horizontal accountability: The legal institutionalization of mistrust. In S. Mainwaring \& C. Welna (Eds.), Democratic accountability in Latin America. Oxford: Oxford University Press.

O'Neill, O. (2002). A question of trust. Cambridge, UK: Cambridge University Press. 
O'Neill, O. (2013). Intelligent accountability in education. Oxford Review of Education, 39(1), 416.

Olssen, M., Codd, J., \& O'Neill, A.-M. (2004). Education policy: Globalization, citizenship and democracy London: Sage.

Ozga, J. (2008). Governing knowledge: Research steering and research quality. European Educational Research Journal, 7(3), 261-272.

Power, M. (1999). The audit society: Rituals of verification. Oxford, UK: Oxford University Press.

Ranson, S. (1986). Towards a political theory of public accountability in education. Local Government Studies, 12(4), 77-98.

Ranson, S. (2003). Public accountability in the age of neo-liberal governance. Journal of Education Policy, 18(5), 459-480.

Rawolle, S. (2010). Understanding the mediatisation of educational policy as practice. Critical Studies in Education, 51(1), 21-39.

Rusbridger, A. (2005, March 9). Hugo Young Lecture: What are newspapers for? Retrieved 5 February, 2015, from http://image.guardian.co.uk/sysfiles/Guardian/documents/2005/03/15/lecturespeech.pdf

Ryan, K. E. (2005). Making educational accountability more democratic. American Journal of Evaluation, 26(4), 532-543.

Sahlberg, P. (2007). Education policies for raising student learning: The Finnish approach. Journal of Education Policy, 22(2), 147-171.

Sahlberg, P. (2010). Rethinking accountability in a knowledge society. Journal of Educational Change, 11(1), 45-61.

Sahlberg, P. (2011). Finnish Lessons: What can the world learn from educational change in Finland? New York: Teachers College Press.

Schedler, A. (1999). Conceptualizing accountability. In A. Schedler, L. J. Diamond \& M. F. Plattner (Eds.), The self-restraining state: Power and accountability in new democracies (pp. 13-28). Boulder, Colorado: Lynne Rienner.

Snyder, I. (2008). Literacy Wars: Why teaching children to read and write is a battleground in Australia. Crows Nest, AU: Allen \& Unwin.

Stack, M. (2006). Testing, testing, read all about it: Canadian press coverage of the PISA results. Canadian Journal of Education, 29(1), 49-69.

Stobart, G. (2008). Testing times: The uses and abuses of assessment. New York: Routledge.

Strøm, K., Müller, W. C., \& Bergman, T. (Eds.). (2003). Delegation and accountability in parliamentary democracies. Oxford: Oxford University Press.

The Courier Mail. (2012a, 30 April). Doomadgee thrives on transformation from woe to go. The Courier Mail, p. 6.

The Courier Mail. (2012b, 30 April). Improvement applauded amid some back-sliding. The Courier Mail, p. 6.

The Courier Mail. (2012c, 5 May). Queensland's best overall NAPLAN results. The Courier Mail, p. 51.

The Courier Mail. (2012d, 30 July). Where to get best education. The Courier Mail, p. 20.

The Courier Mail. (2013, 23 December). State earns gold star for education reforms. The Courier Mail, p. 22.

Thomas, S. (2006). Education policy in the media: Public discourses on education. Teneriffe, AU: Post Pressed. 
Thompson, S. (2011, 15 November). Pupils soar in Naplan tests. NewsMail, p. 8.

Thomson, P., Blackmore, J., Sachs, J., \& Tregenza, K. (2003). High stakes principalshipsleepless nights, heart attacks and sudden death accountabilities: Reading media representations of the United States principal shortage. Australian Journal of Education, 47(2), 118-132.

Wagner, R. B. (1989). Accountability in education: A philosophical inquiry. New York: Routledge.

Warmington, P., \& Murphy, R. (2004). Could do better? Media depictions of UK educational assessment results. Journal of Education Policy, 19(3), 285-299.

West, A., Mattei, P., \& Roberts, J. (2011). Accountability and sanctions in English schools. British Journal of Educational Studies, 59(1), 41-62.

Windle, J. (2009). The limits of school choice: Some implications for accountability of selective practices and positional competition in Australian education. Critical Studies in Education, 50(3), 231-246.

Wu, M. (2010). Measurement, sampling, and equating errors in large-scale assessments. Educational Measurement: Issues and Practice, 29(4), 15-27. 